\title{
Three-Year Clinical Performance of Composite Restorations Placed by Undergraduate Dental Students
}

\author{
Flávio Renato Reis de MOURA ${ }^{1}$ \\ Ana Regina ROMANO ${ }^{2}$ \\ Rafael Guerra LUND ${ }^{3}$ \\ Evandro PIVA ${ }^{3}$ \\ Sinval Adalberto RODRIGUES JÚNIOR ${ }^{4}$ \\ Flávio Fernando DEMARCO ${ }^{3}$
}

\author{
${ }^{1}$ Department of Public Health Dentistry, Lutheran University of Brazil, Cachoeira do Sul, RS, Brazil \\ ${ }^{2}$ Department of Pediatric Dentistry and Preventive Dentistry, UFPel - Federal University of Pelotas, Pelotas, RS, Brazil \\ ${ }^{3}$ Department of Operative Dentistry, UFPel - Federal University of Pelotas, Pelotas, RS, Brazil \\ ${ }^{4}$ Dental School, Community University of Chapecó Region, Chapecó, SC, Brazil
}

\begin{abstract}
This retrospective study evaluated the clinical performance and the reasons for failure of anterior and posterior composite restorations placed by undergraduate dental students over a 3-year period. All cavities were restored using Prime \& Bond 2.1 and TPH (Dentsply), according to the manufacturer's indications. One hundred and two patients who had received composite restorations by third and forth year undergraduate students were recalled and examined to analyze the quality of the restorations. The restorations were evaluated using the modified USPHS system. Two hundred and fifty-six composite restorations, 170 in anterior teeth and 86 in posterior teeth, were evaluated. Eighty-five percent of the restorations were considered satisfactory after 3 years. Class II and class IV restorations presented the highest prevalence of failure. Loss of the restoration and deficient marginal adaptation were the main causes of failure. No restoration failed due to secondary caries. Most restorations placed by dental students were considered satisfactory after long-term evaluation. Failure was more prevalent in larger restorations and was not associated with secondary caries.
\end{abstract}

Key Words: clinical trial, composite resin, dental restorations, secondary caries.

\section{INTRODUCTION}

Despite the significant decrease in caries prevalence worldwide, dental caries is still a significant problem and clinicians spend a considerable amount of time placing restorations to substitute the dental structure lost during caries progression (1). Direct restorations provide a reliable treatment to replace this lost dental structure, with a low cost, less sound dental structure removal and also good clinical performance when compared to indirect restorations (2-4). Amalgam used to be considered the best restorative material for posterior teeth. However, its use has significantly declined due to esthetic reasons and potential toxicity of mercury from amalgam restorations (5).
The introduction of adhesive dentistry allowed the preservation of tooth structure usually lost in cavity preparations for amalgam restorations. However, composites became reliable materials only in the 1980's, with the introduction of visible light-curing technology, adhesion to dentin and improvements in filler technology that resulted in higher filler packing. Beforehand, failure due to insufficient wear resistance, loss of anatomic form and interproximal contacts and general degradation was a common event (3).

In 1990's, composite resin was the material of choice for anterior restorations due to the fulfillment of the esthetic expectations of patients. It was also indicated for posterior restorations, yet in small occlusal or occlusoproximal cavities, preferably with little occlusal 
function and in premolars (6).

A general trend towards adopting composites for posterior restorations in dental schools started in the late 1990 's. An increase of the time dedicated to the teaching of composite restorations was experienced from the 1990 's to the years 2000 (6). Yet, the little experience of the school staff in placing composites in posterior teeth probably limited the quality of the restorations placed by the students (7). Expectations are that the clinical behavior of these restorations might have been favored by the clinical experience acquired during that decade.

The currently available universal composites, either microhybrid, nanohybrid or nanoparticulate, present volumetric shrinkage lower than $4 \%$, mechanical strength, polishability, polish retaining and wear resistance. Such improvements associated to the stateof-the-art placement technique have led to a clinical behavior comparable to that of amalgam restorations (7). In addition, the philosophical shift towards the preservation of tooth structure resulting from the minimal intervention dentistry concept increased the indication of composites as adhesive materials (3).

This retrospective study evaluated the clinical performance and the reasons for failure of class I, II, III and IV composite restorations placed by undergraduate dental students over a 3-year period.

\section{MATERIAL AND METHODS}

The study was approved by the institutional Ethics Committee (Dental School, UFPel) and the patients gave informed writing consent to be included in the study. Information about patients was collected from their dental files at the Dental School of the Federal University of Pelotas, Brazil. Patients who had their teeth restored with composite resin (class I, II, III and IV) by third or forth year dental students were selected.

The restorations were placed by dental students under supervision of a staff member, according to a pre-determined protocol, which included shade selection under natural light prior to isolation, rubber dam isolation, removal of pre-existing restoration or excavation of carious tissue based on tissue consistency criteria associated to caries dye solution. Enamel margins were regularized with gingival margin trimmers. Bevel was performed at the buccal face of the anterior teeth with diamond bur to help masking the restorative interface (8). Proximal space between teeth was guaranteed by pre-wedging with moist wooden wedges or mechanical separators. Class II restorations were performed using transparent matrix band and reflective wedges (TDV Dental Ltda., Pomerode, SC, Brazil). A totaletch adhesive system (Prime \& Bond 2.1; Dentsply Ind. e Com. Ltda, Petrópolis, RJ, Brazil) was applied according to the manufacturer's instructions, and the teeth were restored incrementally with a highly filled hybrid composite (TPH; Dentsply). The restorations were finished with a sequential protocol using fine grit diamond burs and polishing discs (Soflex; 3M ESPE, St. Paul, MN, USA) under water refrigeration (9).

After 3 years, clinical examination and assessment of the quality of the restorations was performed by 2 examiners, calibrated at 2 different moments with a 30day interval (Cohen's Kappa $=0.85$ ). The restorations were evaluated according to the modified USPHS criteria (10), shown in Table 1. Loss of the restoration, fracture of the restoration and loss of the tooth were considered as clinical failure (Table 2). Patients with systemic diseases or periodontal disease, those who refused to participate in the study or did not sign the informed consent form, and those who did not attend to the clinic of the Dental School were excluded from the study.

The statistical software packages used were EPI INFO 6.04 (Centers for Disease Control and Prevention, Atlanta, GA, USA) and STATA 5.0 (Stata Corp LP, College Station, TX, USA), Data were submitted to descriptive analysis to show the prevalence of satisfactory and unsatisfactory restorations regarding the different aspects evaluated, using Chi-square or Fisher's exact test, with confidence level of $95 \%$.

\section{RESULTS}

One hundred and nine patients were eligible for evaluation and 102 were examined with 256 restorations being evaluated. Seven patients refused to participate of the study and were excluded. The mean age of the patients was $36.5( \pm 12.1)$ years. After 3 years of follow up, $85.5 \%$ of the restorations were considered as satisfactory (Table 3).

Class II restorations presented the highest prevalence of failure $(72 \%)$, including restorations classified as unsatisfactory, loss of the restoration and loss of the tooth (Table 3). The second highest prevalence of failure was observed in class IV restorations. Although no class IV restoration was classified as unsatisfactory, $16.7 \%$ of them were lost. More than $90 \%$ of class I and class III restorations were classified as satisfactory (Table 
3). Within the 3-year period, no restoration failed due to secondary caries (Table 4).

\section{DISCUSSION}

The present study evaluated the 3-year survival rate and the reasons for failure of composite restorations placed by dental students. One hundred seventy restorations were placed in anterior teeth (134 class III restorations and 36 class IV restorations) and 86 composite restorations were placed in posterior teeth ( 25 class I restorations and 61 class II restorations). Anterior composite restorations were regularly taught in our Dental School since the 1980's. However, the shift towards using composite in posterior teeth intensified only in the late 1990's. The restorations were placed with bevel at the cavosurface margins, since this procedure could increase the marginal adaptation and sealing ability (8). We have also used a immediate finishing and polishing of restorations in the present study; however, these immediate procedures seem not to affect the quality of composite restorations, when compared to mediate polishing and finishing (9).

The survival rate of anterior restorations was considerably higher for class III than for class IV restorations (91.8 and $77.8 \%$, respectively) and confirms the influence of the restoration size on survival probability (4).

Table 1. Criteria for assessment of composite restorations (modified USPHS - adapted from Barnes et al., ref 10).

\begin{tabular}{|c|c|c|}
\hline Criteria & Score & Description \\
\hline \multirow{3}{*}{$\begin{array}{l}\text { Color } \\
\text { match }\end{array}$} & Alfa & The restoration appears to match the shade and translucency of adjacent tooth tissues. \\
\hline & Bravo & $\begin{array}{l}\text { The restoration does not match the shade and translucency of adjacent tooth tissues, but the mismatch is } \\
\text { within the normal range of tooth shades. }\end{array}$ \\
\hline & Charlie & $\begin{array}{l}\text { The restoration does not match the shade and translucency of adjacent tooth structure, and the mismatch } \\
\text { is outside the normal range of tooth shades and translucency. }\end{array}$ \\
\hline \multirow{3}{*}{$\begin{array}{l}\text { Marginal } \\
\text { staining }\end{array}$} & Alfa & $\begin{array}{l}\text { There is no visual evidence of marginal discoloration different from the color of the restorative material } \\
\text { and from the color of the adjacent tooth structure. }\end{array}$ \\
\hline & Bravo & $\begin{array}{l}\text { There is visual evidence of marginal discoloration at the junction of the tooth structure and the } \\
\text { restorations, but the discoloration has not penetrated along the restoration in a pulpal direction. }\end{array}$ \\
\hline & Charlie & $\begin{array}{l}\text { There is visual evidence of marginal discoloration at the junction of the tooth structure and the } \\
\text { restorations that has penetrated along the restoration in a pulpal direction. }\end{array}$ \\
\hline \multirow{3}{*}{$\begin{array}{l}\text { Surface } \\
\text { roughness }\end{array}$} & Alfa & Surface texture is similar to enamel. \\
\hline & Bravo & Surface texture is similar to conventional composite resin or to white mounted stone. \\
\hline & Charlie & Surface has porosities, impairing the continuous movement of the explorer. \\
\hline \multirow{3}{*}{$\begin{array}{l}\text { Marginal } \\
\text { adaptation }\end{array}$} & Alfa & $\begin{array}{l}\text { The restoration appeared to adapt closely to the tooth. There are no catch or crevice at any point on the } \\
\text { margin. There is no retention of the explorer on the margin. }\end{array}$ \\
\hline & Bravo & $\begin{array}{l}\text { The explorer catches and there is visible evidence of a crevice, which the explorer penetrates, indicating } \\
\text { that the edge of the restoration does not adapt closely to the tooth structure. The dentin and/or the base are } \\
\text { not exposed, and the restoration is not mobile. }\end{array}$ \\
\hline & Charlie & The explorer penetrates crevice defect extended to the dento-enamel junction. \\
\hline \multirow{3}{*}{$\begin{array}{l}\text { Anatomic } \\
\text { form }\end{array}$} & Alfa & The restorations were continuous with existing anatomic form. \\
\hline & Bravo & $\begin{array}{l}\text { The restoration was discontinuous with the existing anatomic form, but the missing material was } \\
\text { insufficient to expose base or dentin. }\end{array}$ \\
\hline & Charlie & Sufficient material has been lost to expose dentin or base. \\
\hline \multirow{2}{*}{$\begin{array}{l}\text { Secondary } \\
\text { caries }\end{array}$} & Alfa & Absence of secondary caries. \\
\hline & Bravo & Presence of secondary caries. \\
\hline
\end{tabular}


No anterior restoration was scored Charlie for color match and marginal staining, properties that usually call for replacement or repair of the restoration, due to the esthetic impact (11). About $15-17 \%$ of the class III and class IV restorations were scored Bravo for color match and about $30 \%$ for marginal staining. The higher percentage of Bravo rating for marginal staining after 3 years might be explained by the little experience of students with the total-etch adhesive technique (12).

Class II and class IV restorations presented the highest prevalence of failures, confirming again the trend of higher failure probability in larger restorations. Indeed, the involvement of proximal surfaces in the restoration has been shown to reduce drastically the survival probability up to 15 years. The same result has been observed when multiple surfaces are involved in the restoration (4).

Taking into consideration all types of restoration, the main cause of failure was the loss of the restoration due to limited adhesiveness $(8.6 \%)$, contrasting with

Table 2. Classification of the restorations.

Classification Characteristics at the evaluation moment

Satisfactory*

Restorations were scored Alfa or Bravo.

Unsatisfactory**

Restorations were scored Charlie or Bravo for the secondary caries criteria.

Restoration lost**

Cavity preparation open, with no restoration.

Restoration fractured**

Presence of fracture in the restoration.

Tooth lost**

Absence of the restored tooth for extraction.

*Considered as clinical success. ${ }^{*}$ Considered as clinical failure. previous studies that point out caries or fracture of the restoration as the main causes of failure of composite restorations $(3,4)$. Debonding of the restorations in the study also might have been caused by the lack of experience of the operators with the adhesive technique. Inexperienced operators have shown less ability to produce restorations with higher bond strength, when compared to experienced operators (12). In class IV restorations the involvement of the incisal angle also generates stresses not observed in other cavity configurations, challenging the interface tooth/ restoration. Also, it is important to highlight that the present study used a simplified acetone-based adhesive system, which has demonstrated lower bond strength than similar ethanol or water based adhesive systems (13), exhibiting worse clinical performance as well (14). In addition, the adhesive system used in this clinical trial has a high rate of volatilization than other adhesive systems (15), and the restorations were performed in a Dental School clinic environment where the bottles could remain more time opened, favoring increased volatilization and impairing the bonding mechanism. All these reasons could contribute to the adhesive failures observed in the present study.

Proximal restorations should be able to reestablish the proximal contacts properly and seal the cervical margins, which have been recognized as the main site of secondary caries lesions. The transparent matrix band and the reflective wedges used in class II restorations were first recommended under the assumption that the composite's directional shrinkage occurred towards the light and could be controlled by application of the light

Table 3. Type of restorations evaluated in the study.

\begin{tabular}{|c|c|c|c|c|c|c|c|c|c|c|}
\hline & \multicolumn{2}{|c|}{ Satisfactory } & \multicolumn{2}{|c|}{ Unsatisfactory } & \multicolumn{2}{|c|}{ Restoration lost } & \multicolumn{2}{|c|}{ Restoration fractured } & \multicolumn{2}{|c|}{ Tooth lost } \\
\hline & No. & $\%$ & No. & $\%$ & No. & $\%$ & No. & $\%$ & No. & $\%$ \\
\hline Class I & 24 & 96.0 & - & - & 1 & 4.0 & - & - & - & - \\
\hline Class II & 44 & 72.1 & 4 & 6.6 & 7 & 11.5 & 2 & 3.3 & 4 & 6.6 \\
\hline Class III & 123 & 91.8 & 1 & 0.8 & 8 & 6.0 & 2 & 1.5 & - & - \\
\hline Class IV & 28 & 77.8 & - & - & 6 & 16.7 & 1 & 2.8 & 1 & 2.8 \\
\hline Total & 219 & 85.5 & 5 & 2.0 & 22 & 8.6 & 5 & 2.0 & 5 & 2.0 \\
\hline
\end{tabular}


through reflective structures, including the tooth itself. This matrix system is no longer used due difficulties of handling and definition of a proper proximal contact area when compared with the metal matrix/wooden wedge system. Even so, similar clinical performance of posterior restorations has been observed in a randomized clinical trial comparing both matrix systems (16).

The present results revealed that no restoration failed due to secondary caries, despite extensive evidence of secondary caries being the main reason for restorative failure and replacement of restorations (3). Such results could be explained by the current concept about secondary caries, which was been recognized as carious lesions located in the margins of existing restorations and dependent upon the sealing, antimicrobial and roughness characteristics of the restorative materials used $(17,18)$. Noteworthy, a systematic review on clinical evaluations of posterior composite restorations showed that the fracture of the restorations was the main reason for restoration failure up to 5 years, while in evaluation periods over 5 years, the main reason for failure was secondary caries (2).
Limitations of marginal seal resulting from the composite's polymerization shrinkage and the longterm degradation of the adhesive system have been pointed out as possible reasons for the development of secondary caries in composite restorations. However, in a 17-year clinical evaluation of light-curable composite restorations bonded with a third generation adhesive system no secondary caries was found (4). Also, a 10-year micromorphological evaluation of composite restorations detected surface deterioration patterns and marginal integrity imperfections from the first years of the restoration in function, features not associated to secondary caries (19).

Recently, in situ evaluations have been undertaken to determine the influence of material's characteristics, namely marginal leakage and surface roughness, biofilm control and fluoride intake on the formation of secondary caries $(17,18)$. Only biofilm control and fluoride intake significantly influenced the formation of caries adjacent to restorations $(17,18)$, indicating a minimum role of the restoration itself and reinforcing the importance of a health promoting approach in which caries prevention

Table 4. Classification of the restorations according to the modified USPHS criteria.

\begin{tabular}{|c|c|c|c|c|c|c|c|c|c|c|c|}
\hline \multirow{2}{*}{ Criteria } & \multirow{2}{*}{ Code } & \multicolumn{2}{|c|}{ Class I } & \multicolumn{2}{|c|}{ Class II } & \multicolumn{2}{|c|}{ Class III } & \multicolumn{2}{|c|}{ Class IV } & \multicolumn{2}{|c|}{ Total } \\
\hline & & No. & $\%$ & No. & $\%$ & No. & $\%$ & No. & $\%$ & No. & $\%$ \\
\hline \multirow{2}{*}{ Color match } & A & 19 & 79.2 & 41 & 85.4 & 105 & 84.7 & 23 & 82.1 & 188 & 83.9 \\
\hline & $\mathrm{B}$ & 5 & 20.8 & 7 & 14.6 & 19 & 15.3 & 5 & 17.9 & 36 & 16.1 \\
\hline \multirow{2}{*}{$\begin{array}{l}\text { Marginal } \\
\text { staining }\end{array}$} & A & 14 & 58.3 & 29 & 60.4 & 88 & 71.0 & 19 & 67.9 & 150 & 67.0 \\
\hline & $\mathrm{B}$ & 10 & 41.7 & 19 & 39.6 & 36 & 29.0 & 9 & 32.1 & 74 & 33.0 \\
\hline \multirow{3}{*}{$\begin{array}{l}\text { Surface } \\
\text { roughness }\end{array}$} & A & 16 & 66.7 & 35 & 72.9 & 70 & 56.5 & 19 & 67.9 & 140 & 62.5 \\
\hline & $\mathrm{B}$ & 8 & 33.3 & 12 & 25 & 54 & 43.5 & 9 & 32.1 & 83 & 37.1 \\
\hline & $\mathrm{C}$ & - & - & 1 & 2.1 & - & - & - & - & 1 & 0.5 \\
\hline \multirow{3}{*}{$\begin{array}{l}\text { Marginal } \\
\text { adaptation }\end{array}$} & A & 16 & 66.7 & 18 & 37.5 & 54 & 43.6 & 13 & 46.4 & 101 & 45.1 \\
\hline & B & 8 & 33.3 & 26 & 54.2 & 70 & 56.5 & 15 & 53.6 & 119 & 53.1 \\
\hline & $\mathrm{C}$ & - & - & 4 & 8.3 & - & - & - & - & 4 & 1.8 \\
\hline \multirow{3}{*}{ Anatomic form } & A & 24 & 100 & 43 & 89.6 & 121 & 97.6 & 20 & 100 & 216 & 96.4 \\
\hline & B & - & - & 4 & 8.3 & 2 & 1.6 & - & - & 6 & 2.7 \\
\hline & $\mathrm{C}$ & - & - & 1 & 2.1 & 1 & 0.8 & - & - & 2 & 0.9 \\
\hline \multirow{2}{*}{$\begin{array}{l}\text { Secondary } \\
\text { caries }\end{array}$} & A & 25 & 100 & 61 & 100 & 134 & 100 & 36 & 100 & 256 & 100 \\
\hline & B & - & - & - & - & - & - & - & - & - & - \\
\hline Total & & 25 & 100 & 61 & 100 & 134 & 100 & 36 & 100 & 256 & 100 \\
\hline
\end{tabular}


and control are the main goal (4). The individuals in this study were treated at the Dental School clinic and received instructions on oral hygiene from dental students during the treatment period, which sometimes takes months. One could speculate that this period had key importance in changing habits towards health for these patients. A recent study has demonstrated that individuals receiving oral health instructions at the age 15 had less need of dental prosthesis at age 24, confirming the importance of dentist's educational role (20).

In conclusion, in the studied population attending a Dental School clinic with a health promotion approach, most restorations placed by dental students could be considered satisfactory after 3 years of evaluation. Failure was more prevalent in larger restorations and was mainly caused by poor adhesiveness, not being associated with secondary caries.

\section{RESUMO}

Este estudo retrospectivo avaliou o comportamento clínico e as razões de falhas de restaurações de resina composta em dentes anteriores e posteriores, realizadas por alunos de graduação em odontologia, após 3 anos de acompanhamento. Cento e dois pacientes que tiveram restaurações de resina composta colocadas por alunos do terceiro ou quarto ano foram rechamados e examinados para analisar a qualidade das restaurações. Todas as cavidades foram restauradas utilizando Prime \& Bond 2.1 e TPH (Dentsply), de acordo com as orientações do fabricante. As restaurações foram avaliadas utilizando o sistema USPHS modificado. Duzentas e cinquenta e seis restaurações de resina composta, $170 \mathrm{em}$ dentes anteriores e $86 \mathrm{em}$ posteriores foram avaliadas. Destas restaurações, $85 \%$ foram consideradas satisfatórias após 3 anos. Cavidades de classe II e classe IV apresentaram maior prevalência de falhas. Perda de restaurações e adaptação marginal deficiente foram as maiores causas de falhas. Nenhuma restauração falhou em decorrência de cárie secundária. Em conclusão, restaurações de resina composta feitas por estudantes de odontologia foram na sua maioria consideradas satisfatórias após 3 anos. Falhas das restaurações foram mais prevalentes em restaurações maiores e não esteve associada com cárie secundária.

\section{REFERENCES}

1. Petersen PE. The world health report 2003: continuous improvement of oral health in the $21^{\text {st }}$ century. The approach of the WHO Global Oral Health Program. Community Dent Oral Epidemiol 2003;31:3-24.

2. Brunthaler A, König F, Lucas T, Sperr W, Schedle A. Longevity of direct resin composite restorations in posterior teeth. Clin Oral Inv 2003;7:63-70.
3. Manhart J, Chen H, Hamm G, Hickel R. Buonocore Memorial Lecture. Review of the clinical survival of direct and indirect restorations in posterior teeth of the permanent dentition. Oper Dent 2004;29:481-508.

4. da Rosa Rodolpho PA, Cenci MS, Donassollo TA, Loguércio $\mathrm{AD}$, Demarco FF. A clinical evaluation of posterior composite restorations: 17-year findings. J Dent 2007;34:427-435.

5. Opdam NJM, Bronkhorst EM, Roeters JM, Loomans BAC. A retrospective clinical study on longevity of posterior composite and amalgam restorations. Dent Mater 2007;23:2-8.

6. Lynch CD, McConnell RJ, Wilson NHF. Trends in the placement of posterior composites in dental schools. J Dent Educ 2007;71:430434.

7. Opdam NJM, Loomans BAC, Roeters FJM, Bronkhorst EM. Fiveyear clinical performance of posterior resin composite restorations placed by dental students. J Dent 2004;32:379-383.

8. Coelho-de-Souza FH, Rocha Ada C, Rubini A, Klein-Júnior CA, Demarco FF. Influence of adhesive system and bevel preparation on fracture strength of teeth restored with composite resin. Braz Dent J 2010;21:327-331.

9. Venturini D, Cenci MS, Demarco FF, Camacho GB, Powers JM Effect of polishing techniques and time on surface roughness, hardness and microleakage of resin composite restorations. Oper Dent 2006;31:11-17.

10. Barnes DM, Blank LW, Gingell JC, Gilner PP. A clinical evaluation of a resin-modified glass ionomer restorative material. J Am Dent Assoc 1995;126:1245-1253.

11. Demirci M, Yildiz E, Uysal Ö. Comparative clinical evaluation of different treatment approaches using a microfilled resin composite and a compomer in class III cavities: two-year results. Oper Dent 2008;33:7-14.

12. Adebayo OA, Burrow MF, Tyas MJ. Bond strength test: role of operator skill. Austral Dent J 2008;53:145-150.

13. Van der Vyver PJ, Dewet FA, Ferreira MR, du Preez IC. Shear bond strength of one-bottle dentine bonding systems. SADJ 2001;56:126-129.

14. Ritter AV, Swift EJ Jr, Heymann HO, Sturdevant JR, Wilder AD Jr. An eight-year clinical evaluation of filled and unfilled one-bottle dental adhesives. J Am Dent Assoc 2009;140:28-37.

15. Lima FG, Moraes RR, Demarco FF, Del Pino FA, Powers J. Onebottle adhesives: in vitro analysis of solvent volatilization and sealing ability. Braz Oral Res 2005;19:278-283.

16. Cenci MS, Lund RG, Pereira CL, de Carvalho RM, Demarco FF. In vivo and in vitro evaluation of Class II composite resin restorations with different matrix systems. J Adhes Dent 2006;8:127-132.

17. Gaengler P, Hoyer I, Montag R, Gaebler P. Micromorphological evaluation of posterior composite restorations - a 10-year report. J Oral Rehabil 2004;31:991-1000.

18. Cenci MS, Tenuta LMA, Pereira-Cenci T, Del Bel Cury AA, ten Cate JM, Cury JA. Effect of microleakage and fluoride on enamel-dentine demineralization around restorations. Caries Res 2008;42:369-379.

19. Lima FG, Romano, AR, Correa MB, Demarco FF. Influence of microleakage, surface roughness and biofilm control on secondary caries formation around composite resin restorations: an in situ evaluation. J Appl Oral Sci 2009;17:61-65.

20. Correa MB, Peres MAA, Peres KG, Horta BL, Gigante DP, Demarco FF. Life-course determinants of need for dental prostheses at age 24. J Dent Res 2010;89:733-738.

Accepted January 14, 2011 